\title{
Post-Secondary Students' Behaviour in the College Choice Decision
}

\author{
Joseph Kee Ming Sia \\ Curtin University, Sarawak Malaysia
}

\begin{abstract}
The objectives of this study are to explore Sarawak post-secondary students' behavior in the college choice decision and to establish the rank of importance of the influencing factors in students' college choice decision. A total of 512 post-secondary students in Sarawak are surveyed using questionnaires. Data collected from the survey is analyzed using Statistical Package for the Social Sciences (SPSS). A series of analyses, including descriptive and factors analysis were conducted on the data. Results suggest that post-secondary students in Sarawak consider programme, cost, location, high school personnel, peers and friends and campus visit as important criteria in selecting higher learning institution. Future research suggested to be carried out is on other aspects that influence student college choice decision such as academic achievement, educational consultant and accreditation. Another direction for future studies is exploration of mediating variable such as parents' expectation and encouragement on college choice decision.
\end{abstract}

Keywords: institution of higher learning, post-secondary students, college choice decision, private higher education institution, marketing in higher education.

\section{Introduction}

Higher Education Institutions (HEIs) face increasing challenges. In particular, their operating environment is undergoing major transformations, such as changing demand patterns, intensifying global competition and decline in funding. Consequently, institutional attention is increasingly focused on attracting high quality (human) resources and students. Such context demands a deeper understanding of which sources postsecondary students resort to when applying to HEIs (Soares and Simoes, 2009).

Malaysia is one such example of which HEIs have undergone a number of significant changes. The growth of HEIs in Malaysia has widened the selection of universities and colleges for students who wish to pursue their tertiary education; this increased the competitive nature of the higher education industry for undergraduate students. This can be seen by the number of students being recruited and the establishment of Private Higher Education Institutions (PHEIs) as discussed below.

From 2002 to 2010, the total number of PHEIs increased from 537 in 2002 to 570 in 2005; however, it dropped to 460 in 2009 due to the decrease in the number of nonuniversity-status private institutions. In 2010, the total number of PHEIs increased slightly to $476 \quad$ (Source: http://www.mohe.gov.my/web_statistik/stat istik2010/BAB3_IPTS.pdf).

Copyright (C) 2011 Joseph Kee Ming Sia. This is an open access article distributed under the Creative Commons Attribution License unported 3.0, which permits unrestricted use, distribution, and reproduction in any medium, provided that original work is properly cited. Contact author: Joseph Kee Ming Sia. E-mail: joseph@curtin.edu.my/ willreply@gmail.com 
The growth in the number of higher education institutions has enabled more students to pursue a tertiary education. In 2009 , there were 437,420 students enrolled in PUHEs in Malaysia. A year later, the total enrollment stood at 462,780 , an increase by 5.8 percent. Total enrollment in PHEIs in 2009 was 484,377. In 2010, the total enrollment in PHEIs increased by 12 percent; that is, 541,629 (Source: http://www.mohe.gov.my/web_statistik/stat istik2010/BAB1_DATA_MAKRO_PENGAJIAN_ TINGGI.pdf).

Tertiary education is arguably a highinvolvement product (Kotler, 1976). For many students and their parents, it represents a substantial investment in monetary and temporal terms. Hence, postsecondary students and their sponsors would look carefully into the options available in the market. Educational marketers must therefore be able to answer these fundamental questions in their marketing attempt: why do students select a particular university from a large number of alternatives? In evaluating the many options available for them, how would students (and their sponsors) come to a purchase decision? On what criteria would they appraise their options (Md. Sidin et al., 2003).

In Malaysia, researchers have studied the college choice decision from a variety of perspectives and have identified a number of variables associated with the student college choice decision process. Md. Sidin et al. (2003) note that academic quality, facilities, campus surroundings and personal characteristics were the most important factors that influence college choice decision. Ancheh, Krishnan and Nurtjahja (2007) reveal that reputation and quality of the institution, nature of institutions, future graduate job prospects, lower costs, affiliation of the institutions and institutions' campus environment and atmosphere were important criteria in college selection process. A study conducted by Baharun (2002) concludes that availability of academic programme, quality of education, administration standards, faculty qualification, and convenient and location were the most important criteria that influence college choice decision. On the other hand, Leow, Ismail, Chen, Lim and Ng (2007) conclude that it is programme, cost, campus visit, and academic reputation.

It is also noted that the researches were mainly conducted in peninsular Malaysia. Moreover, the researches conducted focus mainly on post-purchase behavior rather than pre-purchase behavior. The result may be different if the researches were to be conducted among post-secondary students. This concurs with the literature reported that evaluative criteria might change as the consumption process proceeds, since consumers may have more knowledge regarding some products attributes that were not anticipated before the buying process began (Huang, 2006). Therefore, this study is conducted to fill the gap; that is, to shed more light on post-secondary students' behaviour in Sarawak when selecting a tertiary institution.

In light of these issues, the research objectives of this study are:

1. To explore selection criteria that influence college choice decision.

2. To establish the rank of importance of the influencing factors in college choice decision.

\section{Literature Review}

Studies of college choice decision have typically focused on the issue of factors influencing students' decision about which institution to attend. The combined models show a diversity of factors that influence students' choices. Some factors are related to the role of other persons, some are related to personal or individual factors and others are related to institutional characteristics and students perceptions about value and costs. The following is the discussion of various studies regarding some of the main determinants of college choice decision. 


\section{Cost}

According to Cabrera and La Nasa (2000), research consistently shows a significant negative relationship between tuition increases and enrollment. Foskett, Maringe and Roberts (2006) find out that flexibility of fee payment, availability of financial aid and reasonable accommodation costs exert a significance influence on college choice decision.

Joseph and Joseph (2000) review that costrelated issues seem to have more importance as years go by. For example, Houston (1979) find they were at the bottom of the scale, while in Webb (1993) and Joseph and Joseph (1998) they are one of the most important elements. Jackson (1986) concludes that price is a negative influence on college choice while financial aid to reduce costs is a positive influence.

A study conducted by Yusof et al. (2008) finds that financial assistance offered by universities is one of the four very important attributes expected from a particular higher education institution of choice. Thus, students who receive financial aid awards are more likely to enter college (Jackson, 1988; Litten, 1982; Manski and Wise, 1983).

According to research done by Hossler et al. (1989), $70 \%$ of students and $87 \%$ of parents indicate that they were either "well informed" or "informed" about financial aid programme and their eligibility for financial aid. Some theorists cite that receiving aid is more important than the amount of aid received, because that aid becomes the substantive way through which institutions communicate that "we want to be part of our community" (Jackson, 1982; Abrahamson and Hossler, 1990; Freeman, 1997).

\section{Location}

The geographic location of an institution, or its proximity to home, is another factor that has bearing on students' college choice. A study by Kohn et al. (1976) reveals that an important factor in student predisposition to attend college is the close proximity of a higher education to home. It is found that a low-cost, nearby college was an important stimulator of a student's decision to further his or her education. Wajeeh and Micceri (1997) and Shanka, Quintal and Taylor (2005) also find that the location of an institution has a significant influence on the college choice decision.

\section{High School Personnel}

There have been numerous studies on the impact of guidance counselors in the college selection process. Research indicates that students will discuss the college selection process with their counselors, but that the influence of these counselors varies greatly (Hawkins and Clinedinst, 2006; Hossler and litten, 1993; Hossler et al., 1999; Hossler and Stage, 1987).

Teachers have everyday access to the students and a number of students see these adults as additional, or sometimes primary, sources of information on higher learning institutions. Numerous research studies have confirmed that students look at teachers as part of their information gathering process (Alexander and Eckland, 1975; Coleman and Hoffer, 1987; Lee, Chow-How, Burkham, Gevert and Smerdon, 1998). However, other studies have shown that teachers are not as important as guidance counselors in the college selection process (National PostSecondary Education Cooperative, 2007).

However, surprisingly, other research contrasts the role of teachers and counselors in influencing students on college choice decision (Sevier, 1992). Indeed, Hossler, Braxton and Coopersmith (1989, p.259) suggest that "counselors and teachers have very little influence upon the stimuli stage of most high school students."

\section{Peers and Friends}

To some extent, peers also influence students' college choice. Several studies (Falsey and Haynes, 1984; Joseph and Joseph, 1998; Shanka, Quintal and Taylor, 2005) 
examine the relationship between student interaction with other college-bound students and their college participation. These studies suggest that the more a student interacts with other students with college plans, the more likely he or she will consider going to college. On the other hand, Hossler and Stage (1987) suggest a correction between non-college bound students and their non college bound peers. These researchers state that students with peers with no college plans influence the predisposition phase of students' college choice. Their research also finds that students who were not planning to attend a HEI were more likely to consult their peers. While parental encouragement is still considered the greatest influence on college attainment, the effect of student's peers does add an additional dynamic to the overall college choice process for high school students.

According to Hayden (2000), opinions of friends and former students weigh heavily on the minds of college applicants when deciding between colleges. These studies and others expound upon the knowledge that the more a high school student interacts with other students with college plans, the more likely they are to consider going to college.

Maringe (2006), Hemsley-Brown and Oplatka (2006) find that approximately $27 \%$ of the students turned to their friends and neighbours for their HEI choice. This is because formal sources of interpersonal information such as agents, experts, university staff and counselors are less easily accessed than informal sources such as friends, family, neighbours and relatives. However, formal sources may be more believable if the product is perceived to be highly technical and with high involvement (Coccari et al. 1995).

\section{Programme}

Students' selection of an institution of higher education is also related to another institution characteristic - the type of programmes offered by the institution. Hooley and Lynch (1981) suggest that the suitability of programmes is the most important consideration in students' college choice. Krampf and Heinlein (1981) find that post-secondary students compared programmes offered by various institutions to assess their suitability. Students evaluate programmes according to the following criteria: selection of courses (Qureshi, 1995); availability of courses and entry requirements (Bourke, 2000); quality and variety of education (Shanka, Quintal and Taylor, 2005); and quality and flexibility of degree/course combinations (Holdswoth and Nind, 2006).

\section{Campus Visit}

The campus visit is often a college or a university's best recruiting tools. It is a major factor in the decision-making process (Sevier, 1992). Hossler, Bean and Associates (1990) find that the campus visit was the most important factor influencing student's enrollment decision.

A campus visit provides value to both the student and the institution. A campus visit ensures a good match between the student and the college. Students come to campus with certain expectations such as meeting current students who are like them or instructors who show an interest in them. The personal attention received by the student during a campus visit is a major motivator for college choice decision. In this study, the campus visit is rated by a large number of students as the most important source of information in their college search and choice process. The influence of the campus visit was similar in a study conducted by Lay and Maguire (1981).

\section{Proposed Conceptual Framework}

The conceptual framework is based on the findings presented in the literature reviewed earlier. The proposed conceptual framework for this study is illustrated in figure 1 below. 
Independent variables

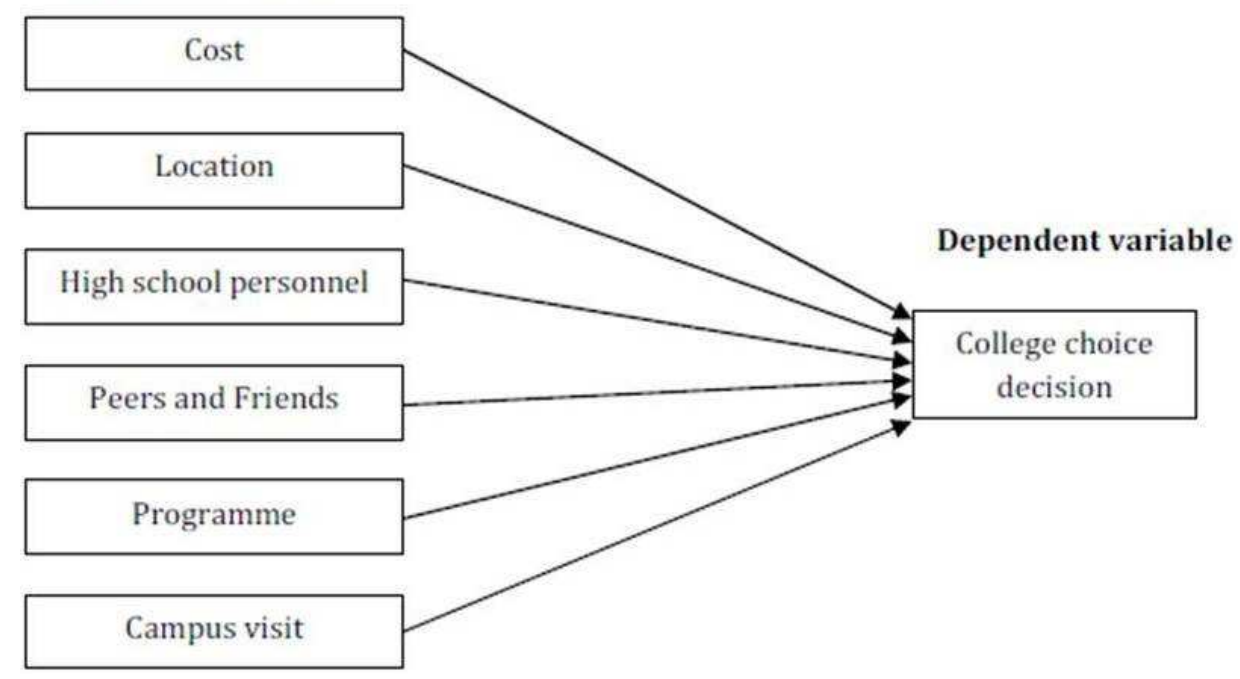

Figure 1: A Conceptual Framework of Post-Secondary Students' Choice Criteria in the Selection of PHEIs

\section{Methodology}

\section{Research Design}

The primary methodology applied will be a quantitative or positivistic descriptive approach. Traditionally, educational research has emphasized the quantitative approach, especially in the field of college choice research (McDonough, 1997). Quantitative descriptive research describes what is - describing, recording, analyzing and interpreting conditions that exist. It involves some type of comparison or contrast and attempts to discover relationship between non-manipulated variables. Some type of statistical analysis is used to describe the results of the study (Sekaran, 2003).

\section{Population of Study}

The population of the survey consists of those post-secondary students in Sarawak who have yet to be admitted into the PHEIs enrolling in undergraduate programmes. In other words, these students will be able to obtain a degree automatically if they complete all academic requirements upon graduation. Students who will be completing their secondary education and who were at the crossroads in choosing the place to further their studies are used in this study in an effort to capture their thoughts regarding college choice decisions because they are experiencing the process of choosing and enrolling in a college. As such, a concern over fading memories will not be an issue. Targeted sample of this study is students who were currently attending or have completed STPM, GCE A-level, UEC, diploma holder, overseas Pre-U(Canadian PreUniversity (CPU), South Australia Matriculation (SAM)), matriculation and university foundation year. The targeted sample is defined as such, as these groups of students have the highest possibility of continuing their study at PHEIs (Lau, 2009).

\section{Sample Size}

Roscoe (1975) proposes the following rules of thumb for determining sample size: 
a) Sample sizes larger than 30 and less than 500 are appropriate for most research.

b) Where samples are to be broken into subsamples; (male/females, juniors/seniors, etc.), a minimum sample size of 30 for each category is necessary.

c) In multivariate research (including multiple regression analyses), the sample size should be several times (preferably 10 times or more) as large as the number of variables in the study.

d) For simple experimental research with tight experimental controls (matched pairs, etc), successful research is possible with samples as small as 10 to 20 in size.

A total of 512 questionnaires were collected from the students. The numbers are considered effective based on the research question investigated (Cavana, Delahaye and Sekaran, 2001; Sekaran, 2003).

\section{Research Instrument}

The instrument is a structured selfadministered questionnaire that was distributed to the respondents in the form of survey and then collected back for use as the primary data.

Basically, the questionnaires contained two sections:

- Section A: Factors that affect college choice decision.

- Section B: Respondents demographic information.

The survey questionnaire used in collecting the data is adopted from the questionnaires developed by Lau (2009), Wagnar and Fard (2009), Joseph and Joseph (2000), Liu (2005), Urbanski (2000), Baharun (2002), Filter (2010), Grieve (2009), Md. Sidin et al. (2003) and Ismail et al. (2010).
The five-point Likert scale, in increasing order, ranging from 1 as "strongly disagree", 2 as "disagree", 3 as "somewhat agree", 4 as "agree" and 5 as "strongly agree" is used in the questionnaire. These formats can be found in section A of the questionnaire. Hair et al. (2006) recommend that Likert scales are the best design when using selfadministered surveys, personal interviews or most online methods to collect data. By definition, the Likert scale is an ordinal scale format asking respondents to indicate whether they agree or disagree about a given object by rating a series of mental belief or behavioural belief statement (Hair et al, 2006). DeVellis (2003) notes that there were few advantages of using Likert scales; that is, it contains items that are easily understood and quantified, accommodates neutral or undecided responses, provides a meaningful way to group a series of items and enables computation of overall scores.

\section{Data Analysis}

SPSS version 16 is used to analyze the collected data. Data was screened and cleaned in order to identify any significant outlier and missing value. Descriptive statistics are employed to calculate the mean of the response to each of the indicators or the variables in the questionnaire as shown in table 1. The frequency is also calculated to understand the breakdown of the respondents. As the research question is to analyze the underlying dimensions of the variables, factor analysis is used.

\section{Survey Response Rate}

The finding reveals that 39.6 percent of the respondents are males and 60.4 percent of the respondents are females. Therefore, it could be said that the female respondents are one third of the total respondents.

In term of ethnicity, it is found that the majority of the respondents are Chinese. The percentage of Chinese respondents is 80.7 
percent, 8.4 percent are Iban respondents, 4.7 percent are Malay respondents and 6.2 percent are categorised as others.

From the finding on educational level of the respondents, 44.5 percent of the respondents are "Sijil Tinggi Persekolahan Malaysia" (STPM) holders, 17.2 percent of the respondents are GCE A-level holders, 2.5 percent of the respondents are UEC holders, 1.2 percent of the respondents are overseas pre-U, 14.3 percent of the respondents are diploma holders, 0.6 percent are matriculation holders and 19.1 percent of the respondents are university foundation holders. This result indicates that most of the respondents are STPM holders.

Regarding the degree programme that the respondents intended to enroll, 28.1 percent of the respondents intended to enroll in Bachelor of Commerce, 17.4 percent of the respondents intended to enroll in Bachelor of Arts, 13.3 percent of the respondents intended to enroll in Bachelor of Engineering, 4.7 percent of the respondents intended to enroll in Bachelor of Technology, 17.4 percent of the respondents intended to enroll in Bachelor of Science, 10.0 percent of the respondents intended to enroll in Bachelor of Business Administration and 9.2 percent of respondents intended to enroll in degree programme other than the above-mentioned.

For PHEIs that the respondents intended to enroll, 27.3 percent intended to enroll in Curtin University, 12.7 percent of the respondents intended to enroll in Swinburne University, 4.5 percent of the respondents intended to enroll Limkokwing University, 6.9 percent of the respondents intended to enroll in UNITAR, 3.5 percent of the respondents intended to enroll in Monash University, 5.3 percent of the respondents intended to enroll in International Medical University, 7.3 percent of the respondents intended to enroll in UTAR, 6.5 percent of the respondents intended to enroll in Taylor's University, 5.1 percent of the respondents intended to enroll in UCSI University, 0.8 percent of the respondents intended to enroll in OUM and 20.2 percent of the respondents intended to enroll in other PHEIs other than the above-mentioned. 
Table 1: Frequency Distribution of Gender, Ethnicity, Respondents' Highest Level of Qualification, Degree Programme Intended to Enroll, PHEIs Intended to Enroll

\begin{tabular}{|c|c|c|c|}
\hline \multicolumn{2}{|c|}{ Variables } & Frequency & Percent \\
\hline \multirow[t]{2}{*}{ Gender } & Male & 203 & 39.6 \\
\hline & Female & 309 & 60.4 \\
\hline \multirow{4}{*}{ Ethnics } & Chinese & 413 & 80.7 \\
\hline & Malay & 24 & 4.7 \\
\hline & Iban & 43 & 8.4 \\
\hline & Others & 32 & 6.2 \\
\hline \multirow{7}{*}{$\begin{array}{c}\text { Respondents' highest level of } \\
\text { qualification }\end{array}$} & STPM & 228 & 44.5 \\
\hline & GCE A-level & 88 & 17.2 \\
\hline & UEC & 13 & 2.5 \\
\hline & Overseas Pre-U & 6 & 1.2 \\
\hline & Diploma & 73 & 14.3 \\
\hline & Matriculation & 3 & 0.6 \\
\hline & University Foundation & 98 & 19.1 \\
\hline \multirow{7}{*}{$\begin{array}{l}\text { Degree programme intended to } \\
\text { enroll }\end{array}$} & B. Commerce & 144 & 28.1 \\
\hline & B. Arts & 89 & 17.4 \\
\hline & B. Engineering & 68 & 13.3 \\
\hline & B. Technology & 24 & 4.7 \\
\hline & B. Science & 89 & 17.4 \\
\hline & B. Business Administration & 51 & 10.0 \\
\hline & Others & 47 & 9.2 \\
\hline \multirow{11}{*}{ PHEIs intended to enroll } & Curtin University & 139 & 27.3 \\
\hline & Swinburne University & 65 & 12.7 \\
\hline & Limkokwing University & 23 & 4.5 \\
\hline & UNITAR & 35 & 6.9 \\
\hline & Monash University & 18 & 3.5 \\
\hline & $\begin{array}{l}\text { International Medical } \\
\text { University }\end{array}$ & 25 & 5.3 \\
\hline & UTAR & 37 & 7.3 \\
\hline & Taylor's University & 33 & 6.5 \\
\hline & UCSI University & 26 & 5.1 \\
\hline & OUM & 4 & 0.8 \\
\hline & Others & 103 & 20.2 \\
\hline
\end{tabular}

\section{Findings and Implications}

The objectives of this research are phrased as "to explore selection criteria that influence college choice decision" and "to establish the rank of importance of the influencing factors in college choice decision." The mean score of the 34 items are first analyzed. All the 34 items have the mean score of more than 3 .
Therefore all the items are included for reliability test.

The study starts with one run for each construct. All items are maintained as Cronbach's Alpha value for the six constructs are greater than 0.7 as shown in table 2 which is consistent with Nunally (1967) and DeVellis (2003). 
Table 2: Reliability Test and Average Mean Score

\begin{tabular}{|l|c|c|}
\hline Factors & Cronbach's Alpha & Average Mean score of the factor \\
\hline Programme & 0.898 & 3.79 \\
\hline Cost & 0.917 & 3.75 \\
\hline Location & 0.912 & 3.68 \\
\hline High school personnel & 0.935 & 3.52 \\
\hline Peers and friends & 0.838 & 3.43 \\
\hline Campus visit & 0.889 & 3.42 \\
\hline
\end{tabular}

Subsequently, factor analysis is conducted. To begin with the data reduction process the six construct, principle component analysis with varimax rotation is carried out on 34 items; suppressed at 0.5. To obtain the orthogonal rotation factors, varimax method is the best analytical approach (Hair et al, 1998). The Kaiser-Meyer-Olkin (KMO) measure of sampling adequacy of this analysis shows the score of 0.916 (table 3) for independent variables and 0.710 (table 4) for dependent variable indicating that the degree of intercorrelation and the appropriateness of using factor analysis as meritorious (Hair et al, 1998). As a result, all the variables survived; 6 items for peer and friends, 5 items for high school personnel, 5 items for cost, 6 items for location, 7 items for programme, 5 items for campus visit and 3 items for college choice decision.

\section{Table 3: KMO and Bartlett's Test for Independent Variables}

\begin{tabular}{|c|r|}
\hline Kaiser-Meyer-Olkin Measure of Sampling Adequacy. & .916 \\
Bartlett's Test of Sphericity Approx. Chi-Square & 12810.222 \\
Df & 561.000 \\
Sig. & .000 \\
\hline
\end{tabular}

Table 4: KMO and Bartlett's Test for Dependent Variable

\begin{tabular}{|c|r|}
\hline Kaiser-Meyer-Olkin Measure of Sampling Adequacy. & .710 \\
Bartlett's Test of Sphericity Approx. Chi-Square & 983.481 \\
Df & 10.000 \\
Sig. & .000 \\
\hline
\end{tabular}

The analysis of the factors that attract postsecondary students in Sarawak to study in PHEIs shows there are six factors. The most influential factor is "programme" with average mean score of 3.79 as found in Appendix 1. The leading most influential criteria that made up this factor is "University has the availability of required degree programme" as it has the highest mean score of 3.96. This indicates that the key motivation that drives the postsecondary students in Sarawak to study in PHEIs is the availability of degree programme. The availability of degree programme means students are able to study at a specific course that suits their interest and ambition. Thus, it is essential that PHEIs offer a wide range of degree programmes to suit different needs of students. 
While acknowledging that availability of degree programme is most important, students are very mindful of the cost as they don't want to be burdened by fees although degree programme meets their expectation. This is evident from the second most influential that is "cost." This factor has the average mean score of 3.75. Among the criteria that make up this factor, the most influential criteria is "university offers scholarships" as it has the mean score 3.95. This provides the evidence that the next major motivation that drives the postsecondary students to choose a particular institution is because the PHEIs offer scholarship with suitability of degree programme. Post-secondary students in Sarawak are assumed to be cost conscious. They are willing to enroll in PHEIs that provides education at a reasonable cost. Furthermore, these students are likely to prefer PHEIs that provides them with financial aid.

The third factor is "location." It is noted that most influential criteria in this factor is "university has an ideal location" and "university is strategically located" with both the mean score of 3.75 .

The fourth key factor is the "high school personnel" which has the average mean scores of 3.52. The most influential criterion that makes up this factor is "high school counselors or teachers discuss the importance of university with me" with the mean score of 3.64. Thus, post-secondary students on college choice decision are influenced by a group of significant people such as high school teachers and counselors.

The fifth key factor is "peers and friends" with the average mean score 3.43. The leading criterion in this factor with mean score 3.64 is "advice from friends who have been studying in university."

Finally, the last factor is the "campus visit" with average mean score of 3.42. The most attractive characteristic in the mean score of
3.57 is "impression of campus visit before enrollment."

\section{Conclusion}

The study aims to explore the important criteria for post-secondary students in Sarawak when choosing a tertiary institution and establish the rank of importance of the influencing factors. Based on the factor analysis results, four factors are significant and positively influence post-secondary students in their decision for selecting higher learning institutions:

a) Programme (range of degree, availability of required degree, flexibility of switching majors, flexible structure and content, specialized programmes, flexible entry requirements and practical components)

b) Cost (financial assistance, education at reasonable cost, scholarships, accommodation at reasonable cost and flexible payment of fees)

c) Location (ideal location, strategically located, convenient and accessible, excellent campus layout, excellent campus size and attractive campus)

d) High school personnel (advice from high school teachers, advice from high school counselors, encouragement from high school counselors, encouragement from high school teachers, discussion with high school teachers and counselors)

It is established that, in order of importance, students consider programme, cost, location and high school personnel to be the most important factor in making decisions before they actually select a higher learning institution. Peers and friends, and campus visit are less important in influencing the college choice decision among the postsecondary students in Sarawak.

Higher learning institutions authorities must be aware of the requested students' needs 
and students' selection criteria. Higher learning institutions should strive to ensure that students are given a holistic educational experience and not just paper qualification. In doing all these, high learning institutions must deliver quality services that will serve the needs and expectations of postsecondary students (Hussin, Tan and Md. Sidin, 2000).

Using the criteria mentioned above, institutions of higher learning could revise their strategy in marketing services. Higher institution administrators and policy makers can now check how far they are providing their services in terms of customer orientation. What area should they improve in order to provide better education for future generations? Findings from the study can help policy makers and administrators develop a better marketing strategy in attracting and retaining students (Hussin, Tan and Md. Sidin, 2000).

Future studies could be carried out on the current students (post-purchase); that is, students who are presently studying in the higher learning institutions to ascertain if the factors influencing student college choice on post-secondary students (pre-purchase) are similar with the current students. In short, a comparative analysis could be done to find out the similarity or differences. Furthermore, future research could also be carried out on other aspects that influence student college choice decision such as academic achievement, educational consultant and accreditation. Another direction for future studies is exploration of mediating variable such as parents' expectation and encouragement on college choice decision.

\section{References}

Abrahamson, T. D. \& Hossler, D. (1990)." Applying Marketing Strategies in Student Recruitment," In D. Hossler and J.P. Bean \& Associates (Eds). The strategic Management of College Enrollments. San Francisco, CA: Jossey-Bass Publishers.
Alexander, K. L. \& Eckland, B. K. (1975). "Basic Attainment Processes: A Replication and Extension," Sociology of Education, 48, 57-95.

Ancheh, K. S. B., Krishnan, A. \& Nurtjahja, 0. (2007). "Evaluative Criteria for Selection of Private Universities and Colleges in Malaysia," Journal of International Management Studies, 2(1). 1-11.

Baharun, R. (2002). 'A Study of Market Segmentation in Tertiary Education for Local Public Higher Learning Institutes,' Malaysian Management Review, 37(1). 1-8.

Bourke, A. (2000). "A Model of the Determinants of International Trade in Higher Education," The Service Industries Journal, 20(1). 110-138.

Cabrera, A. F. \& La Nasa, S. M. (2000). "Using National Databases to Study the College Choice of Low-SES Students," Papers presented at the Annual Meeting of the Association for Institutional Research, Cincinnati, $\mathrm{OH}$.

Cavana, R. Y., Delahaye, B. L. \& Sekaran, U. (2001). Applied Business Research: Qualitative and Quantitative Methods, (1st ed.). John Wiley, Queensland.

Coccari, R. L. \& Javalgi, R. G. (1995). “Analysis of Students' Needs in Selecting a College or Education in a Changing Environment," Journal of Marketing for Higher Education, 6(2). 27-39.

Coleman, J. \& Hoffer, T. (1987). Public and Private High Schools: The Impact of Communities, Basic Books, New York.

DeVellis, R. F. (2003). Scale Development: Theory and Applications (2nd ed.). Sage, Thousand Oaks, California.

Entrant \& Enrolment of Students and Output of Graduates by HEI and Levels of Study, 2009-2010. Retrieved on the 6 May 2011 
from

http://www.mohe.gov.my/web_statistik/stat istik2010/BAB1_DATA_MAKRO_PENGAJIAN_ TINGGI.pdf

Falsey, B. \& Haynes, B. (1984). "The College Channel: Private and Public Schools Reconsidered," Sociology of Higher Education, 57, 111-122.

Filter, S. (2010). "The Choice-of-College Decision of Academically Talented Students", PhD Thesis. The George Washington University, Proquest, UMI Number: 3397600.

Foskett, N., Maringe, F. \& Roberts, D. (2006). "Changing Fee Regimes and their Impact on Student Attitudes to Higher Education," Higher Education Academy, 13(2). 23-31.

Freeman, K. (1997). "Increasing African Americans' Participation in Higher Education: African American students' Perspective," Journal of Higher Education UK, 22(2). 23-31.

Grieve, K. A. (2009). "Urban African American Male High School Students' Educational Aspirations for College and the Influence of Family, School and Peers," Unpublished PhD's thesis, The University of Toledo.

Hair, J. F., Bush, R. P. \& Ortinau, D. J. (2006). Marketing Research: Within a Changing Information Environment , (3rd ed.), McGraw-Hill Irwin, New York.

Hair, J. F., Tatham, R. L., Anderson, R. E. \& Black, W. C. (1998). Multivariate Data Analysis (5th ed.), Prentice-Hall Inc, Upper Saddle River, NJ.

Hawkins, D. A. \& Clinedinst, M. (2006). "The State of College Admission," VA: National Association of College Admission Counseling, Alexandria,

Hemsley-Brown, J. \& Oplatka, I. (2006). "Universities in a Competitive Global Marketplace: A Systematic Review of the Literature on Higher Education Marketing,"
International Journal of Public Sector Management, 19(4). 316-338.

Holdswoth, D. \& Nind, D. (2005). 'Choice Modelling New Zealand High School Seniors' Preferences for University Education,' Journal of Marketing for Higher Education, 15(2). 81-104.

Hooley, G. J. \& Lynch, J. E. (1981). 'Modelling the Student University Choice Process through the Use of the Conjoint Measurement Techniques,' European Research, 9(4). 158170.

Hossler, D., Bean, J. P. \& Associates (1990). The Strategic Management of College Enrollments, Jossey-Bass, Inc, San Francisco.

Hossler, D., Braxton, J. \& Coopersmith, G. (1989). 'Understanding Student College Choice,' In J. C. Smart (Ed.),' Higher Education: Handbook of Theory and Research, 5, 231-288, Agathon Press. New York.

Hossler, D. \& Litten, L. H. (1993). Mapping the Higher Education Landscape, College Board, New York.

Hossler, D., Schmit, J. \& Vesper, N. (1999). "Going to College: How Social, Economic, and Educational Factors Influence the Decisions Students Make," The John Hopkins University Press, Baltimore, Maryland.

Hossler, D. \& Stage, F. K. (1987). 'An Analysis of Student and Parent Data from the Pilot year of the Indiana College Placement and Assessment Center,' Bloomington, IN: Indiana College Placement and Assessment Center.

Houston, M. (1979). 'Cognitive Structure and Information Search Patterns of Prospective Graduate Business Students,' Advances in Consumer Research, VII, October, 552-557.

Huang, W.-Y. (2006). "Measuring Customer Pre-purchase Satisfaction," PhD Thesis. Purdue University. ProQuest LLC, UMI Number: 3251631. 
Hussin, S. R., Tan, H. S. \& Md. Sidin, S. (2000). "Marketing Analysis of the Higher Education Service Sector in Malaysia: Consumer Perspective," Pertanika Journal Social Science and Humanities, 8(1). 1-6.

Ismail, N., Hassan, F., Nooraini, M. S. \& Norzaidi, M. D. (2010). "Determining Mediating Effect of Information Satisfaction on International Students' College Choice: Empirical Evidence in Malaysia's University," International Journal of Scientific Research in Education, 3(1). 51-63.

Jackson, G. (1982). "Public Efficiency and Private Choicer in Higher Education," Educational Evaluation and Policy Analysis, 4(2). 239.

Jackson, G. A. (1986). "Workable, Comprehensive Models of College Choice. Final and Technical Report," Carnegie Foundation for the Advancement of Teaching: National Institute of Education, Washington, D.C: Spencer Foundation, Chicago.

Jackson, G. A. (1988). "Did College Choice Change During the Seventies?," Economics of Education Review 7(1). 15-27.

Johns, R. (2010). "Likert Items and Scales," Survey Question Bank: Methods Fact Sheet .1

Joseph, M. \& Joseph, B. (1998). “Identifying Need of Potential Students in Tertiary Education for Strategy Development," Quality Assurance in Education, 6(2). 90-96.

Joseph, M. \& Joseph, B. (2000). "Indonesian Students' Perceptions of Choice Criteria in Selection of a Tertiary Institution: Strategic Implications," International Journal of Educational Management, 14(1). 40-44.

Kern, C. W. K.. (2000). "College Choice Influences: Urban High School Students Respond," Community college Journal of Research and Practice, 24, 487-494.

Kohn, M., Manski, C. \& Mundel, D. (1976). 'An Empirical Investigation of Factors
Influencing Going Behaviors,' Annual of Economic and Social measurement, 54(4). 391-419.

Kotler, P. (1976). 'Applying Marketing Theory to College Admissions,' In College Entrance Examination Board, A Role for Marketing in College Admission, 54-72, College Entrance Examination Board, New York:.

Krampf, R. F. \& Heinlein, A. C. (1981). "Developing Marketing Strategies and Tactics in Higher Education through Target Market Research," Decision sciences, 12(2). 175-193.

Lau, S. H. (2009). "Higher Education Marketing Concerns: Factors Influencing Malaysian Students' Intention to Study at Higher Educational Institutions," Master Thesis, University of Malaya.

Lay, R. \& Maguire, J. (1981). "Coordinating Market and Evaluation Research on the Admission Rating Process," Research in Higher Education, 14(1). 71-85.

Lay, R. \& Maguire, J. (1981). 'Modelling the College Choice: Image and Decision,' College and University, 56, 113-126.

Lee, V., Chow-Hoy, T. K., Burkham, D. T., Gevert, D. \& Smerdon, B. A. (1998). "Sector Differences in High School Course Taking: A Private School or Catholic School Effect," Sociology of Education, 71, 314-345.

Leow, Y. M., Ismail, N., Chen, C. H., Lim, T. M. \& Ng, F. L. (2007). 'Choice Criteria for Private Tertiary Programmes at a Private Higher Education Institution,' Proceedings of the International Colloquium on Business and Management (ICBM), 19-22 November 2007, Bangkok, Thailand, 1-28.

Litten, L. H. (1982). "Different Strokes in the Applicant Pool: Some Refinements in a Model of Student Choice," Journal of Higher Education, 4, 378. 
Liu, Jianguo (2005). Factors Influencing Students' Choice of Selected Private Universities in China, PhD Thesis. Bringham Young University, Proquest, UMI Number: 3189180

Manski, C. F. \& Wise, D. A. (1983). "College Choice in America," Cambridge, MA: Harvard University Press.

Maringe, F. (2006). "University and Course Choice: Implications for Positioning, Recruitment and Marketing," The International Journal of Educational Management, 20(6). 466-479.

McDonough, P. M. (1994). "Buying and Selling Higher Education: The Social Construction of the College Applicant," Journal of Higher Education, 65(4). 427-445.

Md. Sidin, S., Hussin, S. R. \& Soon, T. H. (2003). "An Exploratory Study of Factors Influencing the College Choice Decision of Undergraduate Students in Malaysia," Asia Pacific Management Review, 8(3). 259-280.

National Post-Secondary Education Cooperative (NPEC) (2007). "Deciding on Postsecondary Education Final Report (NPEC 2008-850)". Washington, DC: Department of Education.

Number of Private HEI by categories, 20092010. Retrieved on the 6 May 2011 from http://www.mohe.gov.my/web_statistik/stat istik2010/BAB3_IPTS.pdf.

Nunnaly, J. C. (1967). Psychometric Theory, McGraw-Hill Book Company, New York.

Qureshi, S. (1995). "College Accession Research: New Variables in an Old Equation," Journal of Professional Services Marketing, 12(2). 163-170.

Roscoe, J. T. (1975). "Fundamental Research Statistics for the Behavioral Sciences," Holt, Rinehart and Winston, Inc, New York.
Sekaran, U. (2003). Research Methods for Business: A Skill Building Approach (4th ed.), John wiley and sons Inc., U.S.

Sevier R. A. (1992). "Recruiting AfricanAmerican Undergraduates: A National Survey of the Factors that Affect Instuitional Choice," College and University, 68, 48-51.

Shanka, T. \& Quintal, V. \& Taylor, R. (2006). "Factors Influencing International Students' Choice of an Education Destination - A Correspondence Analysis," Journal of Marketing for Higher Education, 15(2). 31-46.

Urbanski, R. A. (2000)."Factors Influencing Student College Choice at a Northeastern Minnesota Tribal College," Unpublished Dissertation, University of Minnesota.

Wagner, K. \& Fard, P.-Y. (2009). "Factors Influencing Malaysian Students' Intention to Study at a Higher Educational Institution," Eleader Kuala Lumpur 2009.

Wajeeh, E. M. \& Micceri, T. (1997). "Factors Influencing Students' College Choice at Traditional and Metropolitan Universities," Proceeding of the 37th Annual Forum of the Association for Institutional Research Orlando, Florida.

Webb, M. S. (1993). "Variables Influencing Graduate Business Students' College Selections," College and University Journal, 68(1). 38-46.

Yusof, M., Ahmad, S. N. B., Tajudin, M. \& Ravindran, R. (2008). 'A Study of Factors Influencing the Selection of a Higher Education Institution,' UNITAR e-journal, 4(2), 27-40. 
15 Journal of Marketing Research \& Case Studies

\section{Appendix 1}

\begin{tabular}{|c|c|c|}
\hline Factor 1: Peers and friends (alpha: 0.838 ) & $\begin{array}{l}\text { Factor } \\
\text { Loading }\end{array}$ & $\begin{array}{l}\text { Mean } \\
\text { scores }\end{array}$ \\
\hline Advice from friends to continue their studies in university & 0.779 & 3.45 \\
\hline Advice from peers & 0.746 & 3.37 \\
\hline Advice from friends who have been studying in university & 0.595 & 3.64 \\
\hline Advice from classmates & 0.677 & 3.30 \\
\hline Most friends are attending university & 0.688 & 3.63 \\
\hline My friends influence me to attend university & 0.671 & 3.21 \\
\hline Average mean score for the factor & & 3.43 \\
\hline \multicolumn{3}{|l|}{ Factor 2: High school personnel (alpha: 0.935) } \\
\hline Advice from high school teachers & 0.845 & 3.56 \\
\hline Advice from high school counselors & 0.863 & 3.39 \\
\hline High school counselors encourage me to attend higher education & 0.837 & 3.42 \\
\hline High school teachers encourage me to attend university & 0.831 & 3.61 \\
\hline $\begin{array}{l}\text { High school counselors or teachers discuss the importance of university } \\
\text { with me }\end{array}$ & 0.821 & 3.64 \\
\hline Average mean score for the factor & & 3.52 \\
\hline \multicolumn{3}{|l|}{ Factor 3: Cost (alpha: 0.917) } \\
\hline University offers financial assistance & 0.787 & 3.70 \\
\hline University offers an education at reasonable cost & 0.790 & 3.70 \\
\hline University offers scholarships & 0.771 & 3.95 \\
\hline University makes accommodation available at reasonable costs & 0.755 & 3.74 \\
\hline University makes flexible payment of fees to its students & 0.771 & 3.68 \\
\hline Average mean score for the factor & & 3.75 \\
\hline \multicolumn{3}{|l|}{ Factor 4: Location (alpha: 0.912) } \\
\hline University has an ideal location & 0.762 & 3.75 \\
\hline University is strategically located & 0.744 & 3.75 \\
\hline Location of university is convenient and accessible & 0.678 & 3.74 \\
\hline University has excellent campus layout & 0.754 & 3.65 \\
\hline University has excellent campus size & 0.755 & 3.65 \\
\hline Campus of university is attractive & 0.710 & 3.58 \\
\hline Average mean score for the factor & & 3.68 \\
\hline \multicolumn{3}{|l|}{ Factor 5: Programme (alpha: 0.898) } \\
\hline University has a range of degree & 0.690 & 3.94 \\
\hline University has the availability of required degree programme & 0.735 & 3.96 \\
\hline University has flexibility in allowing switching of majors & 0.675 & 3.66 \\
\hline University has degree programmes with flexible structure and content & 0.768 & 3.72 \\
\hline University has specialised programmes of study available & 0.726 & 3.88 \\
\hline University has flexible entry requirements & 0.674 & 3.64 \\
\hline University has practical components in degree programme & 0.731 & 3.76 \\
\hline Average mean score for the factor & & 3.79 \\
\hline \multicolumn{3}{|l|}{ Factor 6: Campus visit (alpha: 0.889) } \\
\hline Impression of campus visit before enrollment & 0.728 & 3.57 \\
\hline Impression of campus during the open day & 0.728 & 3.51 \\
\hline The attractiveness of the campus during the campus visit & 0.798 & 3.46 \\
\hline Number of students during the campus visit & 0.725 & 3.28 \\
\hline The size of the campus during the campus visit & 0.756 & 3.29 \\
\hline Average mean score for the factor & & 3.42 \\
\hline
\end{tabular}

